\title{
Dynamism in Area, Production and Productivity of Arecanut in Kerala
}

\author{
N Karunakaran ${ }^{*}$
}

\section{Abstract}

Arecanut is an important commercial crop in Kerala. It finds a place in all religious, social and cultural functions of the people of Kerala. Kerala accounts for 22.47 percentage of the area under arecanut in India contributing to 13.70 percentage of national production. During the past five decades, arecanut cultivation has underwent expansion in the area under cultivation associated with increase in production. The analysis of inter-district performance supports this finding. A comparison of the compound growth rates of arecanut productivity during the five periods reveals slight increase in the growth of arecanut productivity and supporting it. The period since the middle of 1980, with regard to area and production the coefficient of variation was higher as compared to 1960's and 1970's. A significant increase in production had occurred consequent to increase in area; however, the productivity of arecanut remains almost stagnant. Nonetheless, for the period since 1985, change in production was mainly due to yield effect. An analysis of the growth of output of arecanut crop in Kerala reveals that the growth is mainly monetary in nature rather than real growth.

Keywords: Arecanut, trend, variability, dynamism, Kerala.

* EKNM Government College Elerithattu, Nilishwar, Kasaragod, Kerala, India; narankarun@gmail.com 


\section{Introduction}

In Kerala, arecanut is cultivated in all districts. The proportion of area under arecanut in the state is very high when compared to the other states (Karunakaran N, 2014). In terms of income, arecanut occupies an important place in the economy of Kerala. Arecanut is predominantly a small farmer's crop. Since more than 75 percentage of the agricultural land holdings are of less than two hectare in size (Govt. of India, 2014), any change in its cultivation either in terms of area, production or productivity would seriously affect the weaker sections of the agriculture population of the state. In spite of its importance, the efficiency of arecanut cultivation attracted very little attention from the researchers in the state. The effort to raise efficiency necessitates investigations into the various aspects of economics of arecanut cultivation. The present study is an attempt to analyze the trend, variability and dynamism of arecanut cultivation against the background of the agricultural sector of Kerala.

\section{Methodology and Materials}

The study is based on secondary data. The major source of secondary data are various published reports of the Department of Economics and Statistics, Thiruvananthapuram, State Planning Board, Thiruvananthapuram, Directorate of Cocoa, Arecanut and spices Development, Kozhikkode and Directorate of Economics and Statistics, Government of India.

For studying the area, production and productivity of arecanut in Kerala, the compound growth rates were calculated using exponential function fitted to the time series data.

$\mathrm{Y}=\mathrm{ab}$

The growth rate (GR) has been computed using the formula:

$\mathrm{GR}=(\text { Antilog } b-1)^{*} 100$

The $\mathrm{F}$ test has been applied to test the significance of $\mathrm{b}$.

An analysis was also carried out to estimate the amount of variability for each of the three variables by computing the coefficient of variation for all the units. 
N Karunakaran Area, Production and Productivity of Arecanut in Kerala

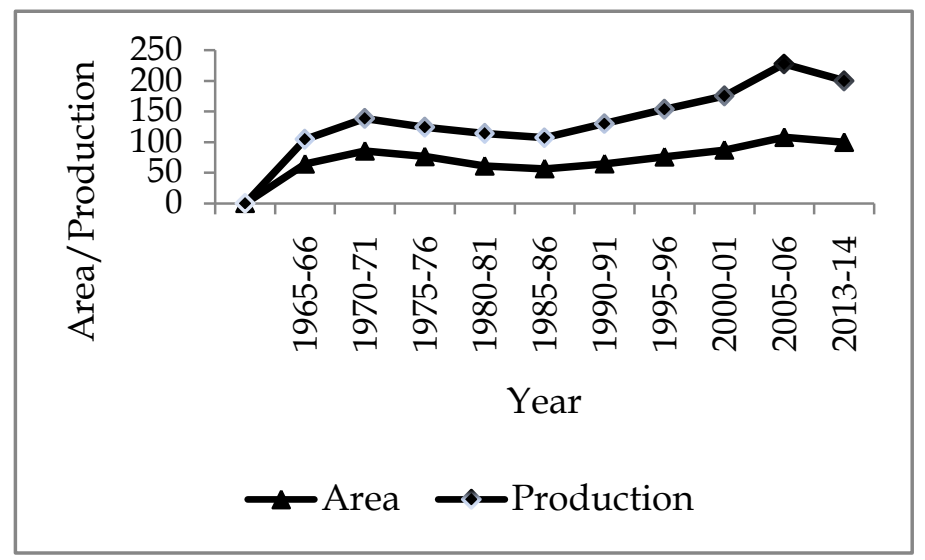

Figure.1 Area and production of arecanut in Kerala

\section{Results and Discussion}

Kerala accounts for 23 percentage of the area under arecanut cultivation in India contributing to fourteen percentage (14\%) of national production. Figure 1 shows the area and production of arecanut during the last five decades. District wise area and production of arecanut in Kerala in 2013-14 is presented in table 1.

\subsection{Trends in Area, Production and Productivity of Arecanut in Kerala}

In this section, an attempt is made to analyze the trends in area, production and productivity of arecanut in Kerala over the period from 1960-61 to 2013-14. The analysis is carried out in terms of growth indices, annual growth rates and is computed by fitting an exponential function to the time series data. 
Table 1 District wise area and production of arecanut in Kerala in 2013-14

\begin{tabular}{|c|c|c|c|c|c|}
\hline $\begin{array}{l}\text { Sl. } \\
\text { No. }\end{array}$ & Districts & $\begin{array}{c}\text { Area } \\
\text { (in } \\
\text { hectare) }\end{array}$ & $\begin{array}{l}\text { Percentage } \\
\text { to total }\end{array}$ & $\begin{array}{l}\text { Production } \\
\text { (in tonnes) }\end{array}$ & $\begin{array}{l}\text { Percentage } \\
\text { to total }\end{array}$ \\
\hline 1 & $\begin{array}{l}\text { Thiruva- } \\
\text { nanthapuram }\end{array}$ & 1001 & 1.00 & 476 & 0.48 \\
\hline 2 & Kollam & 1913 & 1.91 & 1251 & 1.25 \\
\hline 3 & Pathanamthitta & 1210 & 1.21 & 833 & 0.83 \\
\hline 4 & Kottayam & 1581 & 1.58 & 1103 & 1.10 \\
\hline 5 & Alappuzha & 1304 & 1.30 & 513 & 0.51 \\
\hline 6 & Ernakulam & 4463 & 4.46 & 3924 & 3.92 \\
\hline 7 & Idukki & 2381 & 2.38 & 1795 & 1.79 \\
\hline 8 & Trissur & 6424 & 6.42 & 4268 & 4.27 \\
\hline 9 & Palakkad & 9562 & 9.56 & 8402 & 8.40 \\
\hline 10 & Malappuram & 18644 & 18.64 & 18838 & 18.84 \\
\hline 11 & Kozhikkode & 9897 & 9.89 & 8875 & 8.88 \\
\hline 12 & Wayanad & 12181 & 12.18 & 3985 & 3.98 \\
\hline 13 & Kannur & 9959 & 9.96 & 12103 & 12.10 \\
\hline 14 & Kasaragod & 19488 & 19.49 & 33652 & 33.65 \\
\hline 15 & State & 100008 & 100.00 & 100018 & 100.00 \\
\hline
\end{tabular}

Source: - Computed from Cocoa, Arecanut and Spices statistics, Directorate of Cocoa, Arecanut and Spices Development, Kozhikode, Kerala.

\subsubsection{Trends in Arecanut Area}

The area under arecanut cultivation is very high in Kerala as compared to other arecanut producing states. Table 2 presents time series data on area under arecanut, indices of its growth with 196061 as base and annual growth rates over the period from 1960-61 to 2013-14. It reveals that the area under arecanut in Kerala, in the year 1960-61 was 54.2 thousand hectare, reached the peak level of 93.01 thousand hectare in 1974-75 and 100.01 thousand hectare in 2013-14. This observation is further substantiated by the index of area under arecanut and their corresponding annual growth rates. Having examined the area under arecanut, the long term trend in the growth rate over the period from 1960-61 to 2013-14 are estimated for five sub-periods and is presented in Table 3. 
N Karunakaran Area, Production and Productivity of Arecanut in Kerala

Table 2 Trends in area under arecanut in Kerala

\begin{tabular}{|c|c|c|c|}
\hline Year & $\begin{array}{c}\text { Area } \\
\text { (in ‘000 Hectare) }\end{array}$ & $\begin{array}{c}\text { Index of Area } \\
(1960-61=100)\end{array}$ & $\begin{array}{c}\text { Annual growth } \\
\text { Rate }\end{array}$ \\
\hline 1960-61 & 54.26 & 100.00 & - \\
\hline $1961-62$ & 56.74 & 104.57 & 4.57 \\
\hline $1962-63$ & 55.30 & 101.91 & -2.54 \\
\hline $1963-64$ & 56.69 & 104.47 & 2.51 \\
\hline $1964-65$ & 59.49 & 109.63 & 4.93 \\
\hline $1965-66$ & 64.48 & 118.83 & 8.39 \\
\hline $1966-67$ & 71.23 & 131.27 & 10.46 \\
\hline $1967-68$ & 76.04 & 140.14 & 6.75 \\
\hline $1968-69$ & $81-18$ & 149.61 & 6.75 \\
\hline $1969-70$ & 83.68 & 154.22 & 3.08 \\
\hline $1970-71$ & 85.82 & 158.16 & 2.55 \\
\hline $1971-72$ & 86.66 & 159.71 & 0.98 \\
\hline $1972-73$ & 88.63 & 163.40 & 2.27 \\
\hline $1973-74$ & 90.70 & 167.15 & 2.33 \\
\hline $1974-75$ & 93.01 & 171.41 & 2.54 \\
\hline $1975-76$ & 78.62 & 141.20 & -17.62 \\
\hline $1976-77$ & 68.36 & 125.98 & -10.78 \\
\hline $1977-78$ & 62.43 & 115.05 & -8.67 \\
\hline $1978-79$ & 62.32 & 114.85 & -0.17 \\
\hline $1979-80$ & 60.86 & 112.16 & -2.34 \\
\hline $1980-81$ & 61.24 & 112.86 & 0.62 \\
\hline 1981-82 & 61.25 & 112.88 & 0.01 \\
\hline $1982-83$ & 60.82 & 112.08 & -0.70 \\
\hline $1983-84$ & 59.60 & 109.84 & -1.99 \\
\hline $1984-85$ & 59.09 & 108.90 & -0.85 \\
\hline $1985-86$ & 58.69 & 108.16 & -0.67 \\
\hline $1986-87$ & 57.73 & 106.39 & -1.63 \\
\hline $1987-88$ & 60.54 & 111.57 & 4.86 \\
\hline $1988-89$ & 62.47 & 115.13 & 3.19 \\
\hline 1989-90 & 63.21 & 116.48 & 1.35 \\
\hline 1990-91 & 64.80 & 119.42 & 2.94 \\
\hline 1991-92 & 63.40 & 116.84 & -2.58 \\
\hline 1992-93 & 63.92 & 117.77 & 0.93 \\
\hline $1993-94$ & 69.20 & 127.53 & 9.76 \\
\hline 1994-95 & 71.70 & 132.14 & 4.61 \\
\hline $1995-96$ & 70.90 & 130.67 & -1.47 \\
\hline 1996-97 & 76.10 & 140.25 & 9.58 \\
\hline $1997-98$ & 73.30 & 135.09 & -5.16 \\
\hline 1998-99 & 73.63 & 135.72 & 0.63 \\
\hline
\end{tabular}




\begin{tabular}{cccc}
\hline Year & $\begin{array}{c}\text { Area } \\
\text { (in '000 Hectare) }\end{array}$ & $\begin{array}{c}\text { Index of Area } \\
(1960-61=100)\end{array}$ & $\begin{array}{c}\text { Annual growth } \\
\text { Rate }\end{array}$ \\
\hline $1999-00$ & 81.94 & 151.01 & 15.29 \\
$2000-01$ & 87.36 & 161 & 9.99 \\
$2001-02$ & 93.19 & 171.75 & 10.75 \\
$2000-03$ & 97.48 & 179.67 & 7.92 \\
$2003-04$ & 93.38 & 172.1 & -7.57 \\
$2004-05$ & 97.57 & 179.82 & 7.72 \\
$2005-06$ & 108.21 & 199.43 & 19.61 \\
$2006-07$ & 102.08 & 188.13 & -11.3 \\
$2007-08$ & 99.79 & 183.91 & -4.22 \\
$2008-09$ & 96.74 & 178.3 & -5.61 \\
$2009-10$ & 99.22 & 179.08 & 0.78 \\
$2010-11$ & 99.83 & 183.98 & 4.9 \\
$2011-12$ & 101.77 & 187.56 & 3.58 \\
$2012-13$ & 104.55 & 192.68 & 5.12 \\
$2013-14$ & 100.01 & 184.32 & -8.36 \\
\hline
\end{tabular}

Source: - Computed from (i) Statistics for planning (various issues), Department of Economics and Statistics, Govt. of Kerala, Thiruvananthapuram. (ii) Economic Review (various issues), State Planning Board, Govt. of Kerala, Thiruvananthapuram.

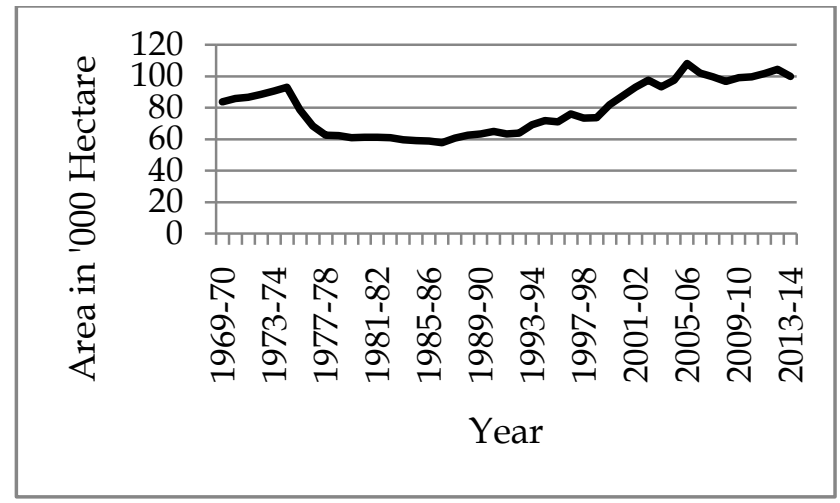

Figure. 2 Trends in area under arecanut in Kerala

Table 3 indicates that the compound growth rate of area under arecanut in Kerala during the entire period of analysis from 1960-61 to 2013-14 is 0.991 percentage per annum. During the first period, the estimated compound growth rate is positive and statistically significant (5.789 percentage per annum). In the second period, the arecanut area registered negative growth rate of -4.849 percentages per annum. But during 1990's and 2000's, significant increase in the growth of arecanut area was observed. 
N Karunakaran Area, Production and Productivity of Arecanut in Kerala

Table 3 Compound Growth Rates of Area of Arecanut in Kerala in Different Periods.

\begin{tabular}{|c|c|c|c|c|c|}
\hline $\begin{array}{c}\text { Period } \\
\text { I } \\
(1960-61 \\
\text { to } \\
1969-70)\end{array}$ & $\begin{array}{c}\text { Period II } \\
(1970-71 \\
\text { to } \\
1979-80)\end{array}$ & $\begin{array}{c}\text { Period } \\
\text { III } \\
(1980-81 \\
\text { to } \\
1989-90)\end{array}$ & $\begin{array}{c}\text { Period } \\
\text { IV } \\
(1990-91 \\
\text { to } \\
\text { 1999-00) }\end{array}$ & $\begin{array}{c}\text { Period } \\
\text { V } \\
(2000-01 \\
\text { to } \\
2013-14)\end{array}$ & $\begin{array}{c}\text { Overall } \\
\text { Period } \\
(1960-61 \\
\text { to } \\
2013-14)\end{array}$ \\
\hline 5.789 & -4.849 & 0.065 & 2.529 & *** 1.436 & 0.991 \\
\hline
\end{tabular}

Table 4 reveals that, out of 14 districts, three districts, Kasaragod, Wayanad and Malappuram accounted about 51 percentage of the total area. The northern districts, Palakkad, Malappuram, Kozhikode, Kannur, Wayanad and Kasaragod accounted for more than 61 percentage of the total area under arecanut in the state; whereas the southern districts Thiruvananthapuram and Kollam account for only 3 percentage of the total area. Table 4 indicates significant difference in the pattern of growth among the growth of area under arecanut in different districts. All the southern districts exhibited negative growth rates in area under arecanut during 1985-86 to 2013-14. The percent growth in area under arecanut among all northern districts exhibited significant increase.

Table 4 Change in Area under arecanut in different Districts in Kerala

\begin{tabular}{lccccc}
\hline \multicolumn{1}{c}{ Districts } & $1985-86$ & $1995-96$ & $2005-06$ & $2013-14$ & $\begin{array}{c}\% \text { increase } \\
\text { over 1985-86 }\end{array}$ \\
\hline Thiruvananthapuram & 2865 & 870 & 1249 & 1001 & -186.21 \\
Kollam & 2823 & 1847 & 2485 & 1913 & -47.57 \\
Pathanamthitta & 1360 & 1308 & 1462 & 1210 & -12.39 \\
Kottayam & 2145 & 1041 & 2081 & 1581 & -35.67 \\
Alappuzha & 2133 & 2073 & 2353 & 1304 & -63.57 \\
Ernakulam & 5259 & 3111 & 5644 & 4463 & -17.83 \\
Idukki & 2333 & 2351 & 4009 & 2381 & 2.02 \\
Trissur & 5982 & 5054 & 8116 & 6424 & 6.88 \\
Palakkad & 2090 & 3434 & 6466 & 9562 & 78.15 \\
Malappuram & 8865 & 14883 & 20022 & 18644 & 52.45 \\
Kozhikkode & 5288 & 9526 & 12478 & 9897 & 46.57 \\
Wayanad & 1243 & 3852 & 10499 & 12181 & 67.65 \\
Kannur & 6441 & 13106 & 14104 & 9959 & 35.32 \\
Kasaragod & 8907 & 12710 & 17622 & 19488 & 54.29 \\
State & 57786 & 70923 & 108207 & 100008 & 42.22 \\
\hline Arear Hed & & & & &
\end{tabular}

Area in Hectare

Source: - Computed from (i) Statistics for planning (various issues), Department of Economics and Statistics, Govt. of Kerala, Thiruvananthapuram. (ii) Economic Review (various issues), State Planning Board, Govt. of Kerala, Thiruvananthapuram. 


\subsubsection{Trends in Arecanut Production}

Arecanut production in Kerala was 7737 million nuts in the year 1960-61, which increased to 12738 million nuts in 1970-71, 13023 million nuts in 1989-90 and100018 million nuts in 2013-14 (Table 5). During the period 1990-91 to 1999-2000, the average annual growth rate was highest percentages per annum. In 2000-01 to 2013-14, the average annual growth rate of arecanut is 10.72 percent per annum.

In order to get a comprehensive picture of the pattern of growth of arecanut production in Kerala, the exponential growth equation for 1960-61 to 2013-14 is estimated and the summary results are presented in table 6 .

Table 5 Trends in arecanut production in Kerala

\begin{tabular}{cccc}
\hline Year & $\begin{array}{c}\text { Production } \\
\text { (in million nuts) }\end{array}$ & $\begin{array}{c}\text { Index of } \\
\text { Production } \\
(1960-61=100\end{array}$ & $\begin{array}{c}\text { Annual } \\
\text { Growth Rate }\end{array}$ \\
\hline $1960-61$ & 7737 & 100.00 & - \\
$1961-62$ & 8091 & 104.57 & 4.57 \\
$1962-63$ & 8312 & 107.43 & 2.73 \\
$1963-64$ & 8522 & 110.14 & 2.52 \\
$1964-65$ & 8945 & 115.61 & 4.96 \\
$1965-66$ & 9681 & 125.12 & 8.22 \\
$1966-67$ & 10683 & 138.07 & 10.35 \\
$1967-68$ & 11473 & 148.28 & 7.39 \\
$1968-69$ & 12289 & 158.83 & 7.11 \\
$1969-70$ & 12661 & 163.64 & 3.02 \\
$1970-71$ & 12738 & 164.63 & 0.60 \\
$1971-72$ & 12832 & 165.85 & 0.74 \\
$1972-73$ & 13136 & 169.78 & 2.36 \\
$1973-74$ & 13459 & 173.95 & 2.45 \\
$1974-75$ & 13777 & 178.06 & 2.36 \\
$1975-76$ & 11387 & 147.17 & -17.34 \\
$1976-77$ & 11303 & 146.09 & -0.73 \\
$1977-78$ & 10548 & 136.33 & -6.68 \\
$1978-79$ & 10919 & 141.12 & 3.51 \\
$1979-80$ & 10829 & 139.96 & -0.82 \\
$1980-81$ & 10805 & 139.65 & -0.22 \\
$1981-82$ & 10702 & 138.32 & -0.95 \\
$1982-83$ & 11027 & 142.52 & 3.03 \\
$1983-84$ & 8318 & 107.50 & -24.57 \\
$1984-85$ & 9269 & 119.80 & 11.44 \\
$1985-86$ & 10664 & 137.83 & -0.95 \\
$1986-87$ & 10563 & 136.52 & \\
\hline
\end{tabular}


N Karunakaran Area, Production and Productivity of Arecanut in Kerala

\begin{tabular}{|c|c|c|c|}
\hline Year & $\begin{array}{c}\text { Production } \\
\text { (in million nuts) }\end{array}$ & $\begin{array}{c}\text { Index of } \\
\text { Production } \\
(1960-61=100\end{array}$ & $\begin{array}{c}\text { Annual } \\
\text { Growth Rate }\end{array}$ \\
\hline $1987-88$ & 10666 & 137.85 & 0.97 \\
\hline $1988-89$ & 11450 & 147.99 & 7.35 \\
\hline $1989-90$ & 13023 & 168.32 & 13.73 \\
\hline $1990-91$ & 13074 & 168.98 & 0.66 \\
\hline $1991-92$ & 13116 & 169.52 & 054 \\
\hline $1992-93$ & 13643 & 176.33 & 6.81 \\
\hline 1993-94 & 15357 & 198.49 & 22.16 \\
\hline 1994-95 & 17466 & 225.75 & 27.26 \\
\hline $1995-96$ & 17429 & 225.27 & -0.48 \\
\hline $1996-97$ & 17175 & 221.99 & -3.28 \\
\hline $1997-98$ & 87038 & 1124.96 & 902.97 \\
\hline $1998-99$ & 68479 & 855.08 & -269.88 \\
\hline 1999-00 & 83337 & 1141.75 & 286.67 \\
\hline 2000-01 & 84527 & 1092.5 & -49.25 \\
\hline 2001-02 & 84681 & 1094.49 & 1.00 \\
\hline $2000-03$ & 92039 & 1189.6 & 95.11 \\
\hline 2003-04 & 105490 & 1363.45 & 173.85 \\
\hline 2004-05 & 106389 & 1375.07 & 11.62 \\
\hline 2005-06 & 110309 & 1542.06 & 167 \\
\hline 2006-07 & 109968 & 1421.33 & -120.73 \\
\hline 2007-08 & 114690 & 1482.36 & 61.03 \\
\hline 2008-09 & 124623 & 1610.74 & 128.38 \\
\hline $2009-10$ & 127893 & 1612.9 & 2.16 \\
\hline $2010-11$ & 99909 & 1291.31 & -321.59 \\
\hline 2011-12 & 121623 & 1571.96 & 280.65 \\
\hline $2012-13$ & 118233 & 1528.15 & -43.81 \\
\hline 2013-14 & 100018 & 1292.72 & -235.43 \\
\hline
\end{tabular}

Source: - Computed from (i) Statistics for planning (various issues), Department of Economics and Statistics, Govt. of Kerala, Thiruvananthapuram. (ii) Economic Review (various issues), State Planning Board, Govt. of Kerala, Thiruvananthapuram.

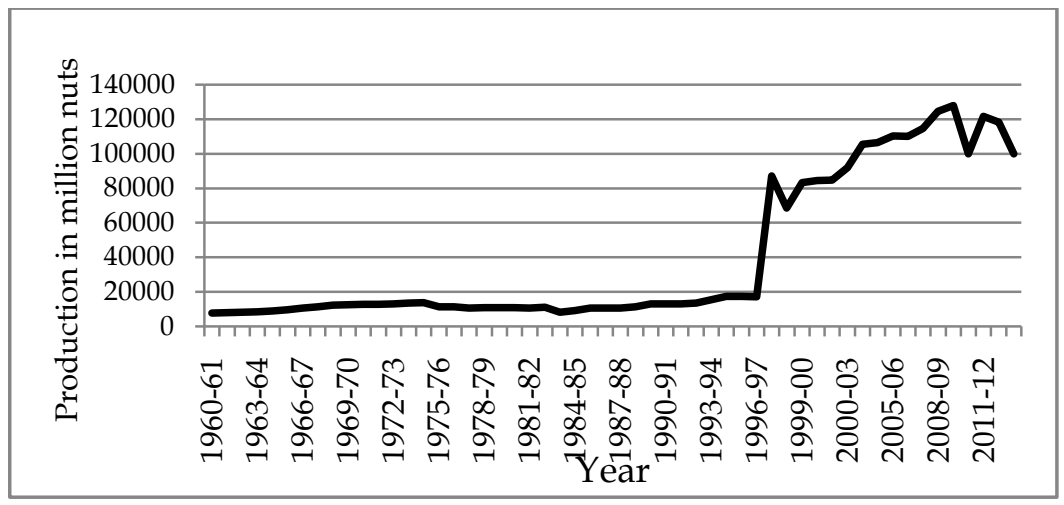

Figure 3 Trends in arecanut production in Kerala 
Table 6 Compound Growth Rates of Production of Arecanut in Kerala in Different Periods.

\begin{tabular}{cccccc}
\hline $\begin{array}{c}\text { Period } \\
\text { I }\end{array}$ & Period & Period & Period & Period & Overall \\
II & III & IV & V & Period \\
$(1960-61$ & $(1970-71$ & $(1980-81$ & $(1990-91$ & $(2000-01$ & $(1960-61$ \\
to & to & to & to & to & to \\
$1969-70)$ & $1979-80)$ & $1989-90)$ & $1999-00)$ & $2013-14)$ & $2013-14)$ \\
\hline 6.072 & -2.633 & 1.269 & 25.775 & 5.025 & 5.575 \\
\hline
\end{tabular}

Table 6 indicates that the compound growth rate of arecanut production in Kerala during the entire period of analysis (1960-61 to 2013-14) is 5.75 percent per annum. During the Period I, the estimated compound growth rate is positive and statistically significant (6.07 percentage per annum). A comparison of the compound growth rate of arecanut production during different periods revealed that significant decline in the growth of arecanut production was observed during the period II.

At this stage it would be interesting to analyze the pattern of growth of arecanut production in different districts. Table 7 presents the district wise arecanut production in Kerala. The table indicates that the three districts Kasaragod, Kannur and Malappuram account for 65 percentage of the total production. Whereas the southern districts Thiruvananthapuram, Kollam, Pathanamthitta, Alappuzha and Kottayam account for only 4 percent of the total arecanut production in 2013-14. An intertemporal comparison of the district wise share of the arecanut production revealed fluctuations in their share values.

Table 7 Change in arecanut Production in different Districts in Kerala

\begin{tabular}{lccccc}
\hline \multicolumn{1}{c}{ Districts } & $1985-86$ & $1995-96$ & $2005-06$ & $2013-14$ & $\begin{array}{c}\text { \% increase } \\
\text { over 1985-86 }\end{array}$ \\
\hline Thiruvananthapuram & 363 & 98 & 690 & 476 & 23.34 \\
Kollam & 426 & 313 & 1794 & 1251 & 65.94 \\
Pathanamthitta & 340 & 290 & 1637 & 833 & 59.18 \\
Kottayam & 302 & 130 & 1201 & 1103 & 72.62 \\
Alappuzha & 262 & 246 & 950 & 513 & 48.92 \\
Ernakulam & 1303 & 506 & 6050 & 3924 & 66.79 \\
Idukki & 319 & 826 & 4669 & 1795 & 82.23 \\
Trissur & 1180 & 1857 & 10661 & 4268 & 72.35 \\
Palakkad & 335 & 574 & 6290 & 8402 & 96.01 \\
Malappuram & 1408 & 2861 & 15621 & 18838 & 92.52 \\
Kozhikkode & 1117 & 2473 & 14522 & 8875 & 87.41 \\
Wayanad & 226 & 601 & 6035 & 3985 & 94.32 \\
Kannur & 1353 & 2894 & 16486 & 12103 & 88.82
\end{tabular}


N Karunakaran Area, Production and Productivity of Arecanut in Kerala

\begin{tabular}{lccccc} 
Kasaragod & 1730 & 3760 & 32701 & 33652 & 94.86 \\
State & 10664 & 17429 & 119309 & 100018 & 89.34 \\
\hline
\end{tabular}

Production in tonnes

Source: - Computed from (i) Statistics for planning (various issues), Department of Economics and Statistics, Govt. of Kerala, Thiruvananthapuram. (ii) Economic Review (various issues), State Planning Board, Govt. of Kerala, Thiruvananthapuram.

\subsubsection{Trends in Arecanut Productivity}

The productivity levels, indices of growth and the annual growth rates are presented in table 8 . It is seen from the table that the productivity of arecanut in Kerala increased from 142601 nuts per hectare in 1960-61 to 199399 nuts per hectare in 2013-14. From 196061 to 1975-76 the productivity index of arecanut in Kerala remains almost stagnant. Thereafter, the yield levels have been gradually increasing.

Table 8 Trends in Productivity of arecanut in Kerala

\begin{tabular}{cccc}
\hline Year & $\begin{array}{c}\text { Productivity } \\
\text { (nuts per hectare) }\end{array}$ & $\begin{array}{c}\text { Index of productivity } \\
(1960-61=100)\end{array}$ & $\begin{array}{c}\text { Annual growth } \\
\text { rate }\end{array}$ \\
\hline $1960-61$ & 142601 & 100.00 & - \\
$1961-62$ & 142598 & 99.99 & -0.01 \\
$1962-63$ & 150317 & 105.41 & 5.42 \\
$1963-64$ & 150310 & 105.40 & 0.00 \\
$1964-65$ & 150360 & 105.44 & 0.03 \\
$1965-66$ & 150360 & 105.44 & 0.00 \\
$1966-67$ & 149976 & 105.17 & -0.25 \\
$1967-68$ & 150873 & 105.80 & 0.59 \\
$1968-69$ & 151376 & 106.15 & 0.33 \\
$1969-70$ & 151303 & 106.10 & -0.04 \\
$1970-71$ & 148430 & 104.08 & -1.90 \\
$1971-72$ & 148074 & 103.83 & -0.24 \\
$1972-73$ & 148207 & 103.93 & 0.09 \\
$1973-74$ & 148389 & 104.05 & 0.11 \\
$1974-75$ & 148120 & 103.87 & -0.17 \\
$1975-76$ & 148620 & 104.22 & 0.33 \\
$1976-77$ & 165354 & 115.95 & 11.25 \\
$1977-78$ & 168965 & 118.48 & 2.18 \\
$1978-79$ & 175214 & 122.87 & 3.70 \\
$1979-80$ & 177938 & 124.78 & 1.55 \\
$1980-81$ & 176431 & 123.72 & -0.84 \\
$1981-82$ & 174723 & 122.52 & -0.96 \\
$1982-83$ & 181317 & 127.14 & 3.77 \\
$1983-84$ & 139554 & 97.86 & -23.02 \\
$1984-85$ & 156865 & 110.00 & 12.40 \\
$1985-86$ & 181697 & 127.41 & 15.82 \\
$1986-87$ & 182959 & 128.30 & 0.69 \\
& & &
\end{tabular}




\begin{tabular}{cccc}
$1987-88$ & 176195 & 123.55 & -3.70 \\
$1988-89$ & 183282 & 128.52 & 4.02 \\
$1989-90$ & 199399 & 139.83 & 8.80 \\
$1990-91$ & 201759 & 141.48 & 1.65 \\
$1991-92$ & 206877 & 145.07 & 3.59 \\
$1992-93$ & 213505 & 149.72 & 4.65 \\
$1993-94$ & 221922 & 155.62 & 5.9 \\
$1994-95$ & 243598 & 170.82 & 15.2 \\
$1995-96$ & 245825 & 172.38 & 1.56 \\
$1996-97$ & 225690 & 158.26 & -14.12 \\
$1997-98$ & 1187422 & 832.68 & 674.42 \\
$1998-99$ & 929916 & 652.11 & -180.57 \\
$1999-00$ & 1017049 & 713.21 & 61.10 \\
$2000-01$ & 967571 & 678.51 & -34.70 \\
$2001-02$ & 908692 & 637.22 & -41.29 \\
$2000-03$ & 944087 & 662.04 & 24.82 \\
$2003-04$ & 1129685 & 792.19 & 130.15 \\
$2004-05$ & 1090386 & 764.64 & -27.55 \\
$2005-06$ & 1102569 & 773.81 & 9.17 \\
$2006-07$ & 1069936 & 750.30 & -23.51 \\
$2007-08$ & 1149000 & 805.74 & 55.44 \\
$2008-09$ & 1238000 & 868.15 & 62.41 \\
$2009-10$ & 1289000 & 903.92 & 35.77 \\
$2010-11$ & 1001000 & 701.95 & -201.97 \\
$2011-12$ & 1163000 & 815.56 & 113.61 \\
$2012-13$ & 1100000 & 771.38 & -44.18 \\
$2013-14$ & 1000000 & 701.25 & -70.13 \\
\hline
\end{tabular}

Source: - Computed from (i) Statistics for planning (various issues), Department of Economics and Statistics, Govt. of Kerala, Thiruvananthapuram. (ii) Economic Review (various issues), State Planning Board, Govt. of Kerala, Thiruvananthapuram.

In order to get a precise idea about the pattern of growth of arecanut productivity exponential growth equations are estimated for period 1960-61 to 2013-14. The results are presented in table 9. The estimated compound growth rate of arecanut productivity in Kerala during the entire period of analysis is 4.84 percent per annum. A comparison of the growth rate of arecanut productivity in table 9reveals that during the different sub-periods, growth rate of arecanut productivity was positive.

The district wise productivity of arecanut is given in table 10 which reveals that Palakkad, Kannur and Kasaragod districts have productivity levels higher than that of the state average during 2013-14. The yield level was highest in Kasaragod district followed by Kannur. It was lowest in Alappuzha district. Between 1985-86 
and 2013-14, highest increase in productivity of arecanut was observed in Kasaragod district.

Table 9 Compound Growth Rates of Productivity of Arecanut in Kerala in Different Periods.

\begin{tabular}{cccccc}
\hline $\begin{array}{c}\text { Period I } \\
(1960-61 \\
\text { to }\end{array}$ & $\begin{array}{c}\text { Period II } \\
(1970-71 \\
\text { to }\end{array}$ & $\begin{array}{c}\text { Period III } \\
(1980-81 \\
\text { to } \\
1969-70)\end{array}$ & $\begin{array}{c}\text { Period IV } \\
(1990-91 \\
\text { to }\end{array}$ & $\begin{array}{c}\text { Period V } \\
(2000-01 \\
\text { to }\end{array}$ & $\begin{array}{c}\text { Overall } \\
\text { Period } \\
(1960-61 \\
\text { to }\end{array}$ \\
\hline$* 0.585$ & 2.329 & $1989-90)$ & $1999-00)$ & $2013-14)$ & $2013-14)$ \\
\hline
\end{tabular}

* - Significant at probability level 0.01

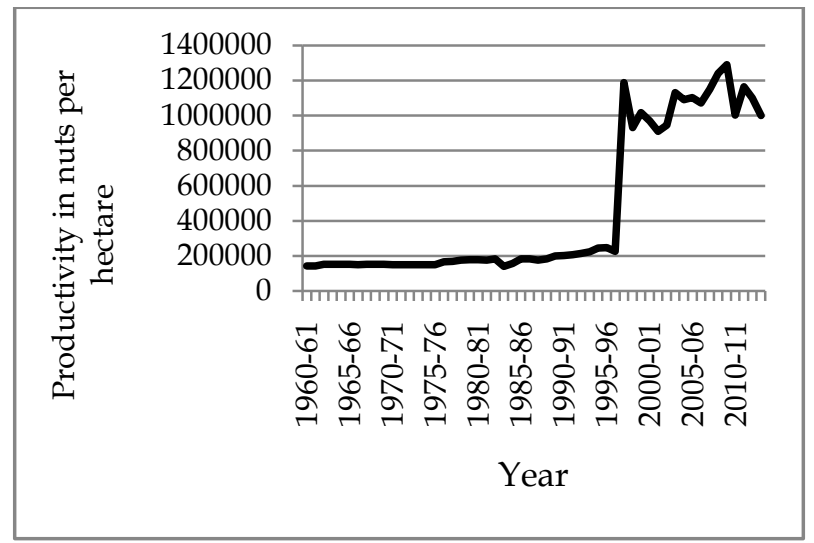

Figure 4 Trends in Productivity of arecanut in Kerala

Table 10 Change in arecanut Productivity in different Districts in Kerala

\begin{tabular}{lccccc}
\hline \multicolumn{1}{c}{ Districts } & $1985-86$ & $1995-96$ & $2005-06$ & $2013-14$ & $\begin{array}{c}\text { \% increase } \\
\text { over 1985-86 }\end{array}$ \\
\hline Thiruvananthapuram & 99 & 112 & 552 & 510 & 80.58 \\
Kollam & 127 & 169 & 722 & 821 & 84.53 \\
Pathanamthitta & 250 & 221 & 1120 & 619 & 59.61 \\
Kottayam & 140 & 124 & 404 & 728 & 80.77 \\
Alappuzha & 122 & 118 & 577 & 408 & 70.09 \\
Ernakulam & 247 & 162 & 1072 & 939 & 73.69 \\
Idukki & 136 & 224 & 1165 & 925 & 85.29 \\
Trissur & 197 & 311 & 1314 & 666 & 70.42 \\
Palakkad & 160 & 167 & 973 & 1255 & 87.25 \\
Malappuram & 158 & 192 & 780 & 1163 & 86.41 \\
Kozhikkode & 211 & 259 & 1164 & 1069 & 80.26 \\
Wayanad & 181 & 156 & 575 & 525 & 65.52 \\
Kannur & 210 & 220 & 1169 & 1303 & 83.88 \\
Kasaragod & 194 & 295 & 1856 & 1953 & 90.06 \\
State & 181 & 245 & 1099 & 1163 & 84.44 \\
\hline
\end{tabular}

Productivity in $\mathrm{Kg}$ per hectare

Source: - Computed from (i) Statistics for planning (various issues), Department of Economics and 
Statistics, Govt. of Kerala, Thiruvananthapuram. (ii) Economic Review (various issues), State Planning Board, Govt. of Kerala, Thiruvananthapuram.

\subsection{Variability in Area, Production and Productivity of Arecanut}

In this section, it was attempted to specify the magnitude of changes that have happened in area, production and productivity by computing coefficients of variation for Period I and Period II, separately for nine districts in period I and for all districts in period II. The results are presented in table 11.

Considering the area, a perceptible change has been evident during the first period and was marginal in all districts. During the second period, Thiruvananthapuram, Palakkad and Wayanad districts have indicated a very high variation in area. For the state as a whole, the size of variation in arecanut area has been 12.18 in the first period and was 28.26 in the second period. In Thiruvananthapuram and Palakkad districts the coefficient of variation was higher in period II as compared to period I; but in Kollam and Trissur districts it was higher in period I as against period II.

The coefficient of variation in production for the state as a whole was 14.87 during the period I, while it was 90.26 in the second period. In period I, the coefficient of variation was observed to be highest in Kollam district and lowest in Alappuzha district. In the second period Palakkad district recorded highest variation and was lowest in Thiruvananthapuram district. Here also there is interdistrict variation in both the periods.

Table 11 Coefficient of variation in area, production and productivity of arecanut in different districts of Kerala

\begin{tabular}{lcccccc}
\hline \multicolumn{1}{c}{ Districts } & \multicolumn{2}{c}{ Area } & \multicolumn{2}{c}{ Production } & \multicolumn{2}{c}{ Productivity } \\
& Perio & Period & Period & Period & Period & Period \\
& d I & II & I & II & I & II \\
\hline Thiruvananthapuram & 15.30 & 61.88 & 19.99 & 60.59 & 8.52 & 77.39 \\
Kollam & 31.26 & 20.66 & 41.68 & 74.32 & 17.03 & 78.87 \\
Pathanamthitta & - & 7.86 & - & 80.61 & - & 75.92 \\
Kottayam & 22.71 & 29.99 & 31.98 & 79.88 & 15.75 & 81.20 \\
Alappuzha & 14.05 & 23.26 & 14.88 & 66.65 & 19.98 & 73.75 \\
Ernakulam & 22.28 & 24.23 & 18.98 & 85.97 & 15.04 & 77.17 \\
Idukki & - & 29.88 & - & 102.16 & - & 83.29 \\
Trissur & 32.19 & 20.05 & 25.48 & 96.20 & 6.86 & 80.82 \\
Palakkad & 20.62 & 61.81 & 20.42 & 104.41 & 11.06 & 87.78 \\
Malappuram & - & 31.97 & - & 91.23 & - & 84.76
\end{tabular}


N Karunakaran Area, Production and Productivity of Arecanut in Kerala

$\begin{array}{lcccccc}\text { Kozhikkode } & 23.47 & 32.02 & 29.63 & 91.74 & 13.67 & 75.58 \\ \text { Wayanad } & - & 75.35 & - & 102.76 & - & 61.63 \\ \text { Kannur } & 22.73 & 31.72 & 19.41 & 88.66 & 10.68 & 81.60 \\ \text { Kasaragod } & - & 32.66 & - & 97.95 & - & 89.35 \\ \text { State } & 17.18 & 28.26 & 14.87 & 90.26 & 4.99 & 79.06\end{array}$

Period I (1960-61 to 1984-85) and Period II (1985-86 to 2013-14).

As regards productivity, the extent of variation of second period is considerably higher than that in the first period in all the districts. For the state as a whole, the size of variation in arecanut productivity was nearly twenty times more in the second period than that recorded in the first period.

Fluctuations in the production of arecanut can be due to:

1. Area effect: It reflects the impact of growth of average area on the increase in the level of production, keeping all other influences inoperative during the period.

2. Yield effect: It reflects the impact of the growth of average yield

3. Cropping pattern effect: It reflects the impact of cropping pattern changes during the current period as compared to the base period.

4. Interaction effect between yield and cropping pattern signifies the influence of these factors over others in bringing about the changes in production. These four factors show the disaggregation of the real component.

5. Pure price effect, that is, an increase of this magnitude in the value of output is solely due to rise in prices.

6. Interactions between price and yield effect, that is, interaction between the two variables considered.

7. Interactions between price and cropping pattern effect, that is, interaction between the two variables considered and

8. Total interaction effect, that is, interaction between the three variables; changes in prices, cropping pattern and yields. 
Table 12 Decomposition of growth of output of arecanut crop in Kerala.

\begin{tabular}{clc}
\hline Sl. No. & \multicolumn{1}{c}{ Elements } & $\begin{array}{c}\text { Growth of output of Arecanut crop } \\
\text { (in \% ) }\end{array}$ \\
\hline 1 & Increase in value of output & 44543.71 \\
2 & Area effect & 0.18 \\
3 & Yield effect & 3.06 \\
4 & Cropping pattern effect & 0.22 \\
5 & Interaction effect & 1.77 \\
6 & Real Growth (2+3+4+5) & 5.23 \\
7 & Pure price effect & 6.78 \\
8 & Price Yield effect & 54.37 \\
9 & Price cropping pattern effect & 3.73 \\
10 & Total Interaction effect & 29.89 \\
11 & Monetary Growth (7+8+9+10) & 94.77 \\
12 & Total (6 +11) & 100.00 \\
\hline
\end{tabular}

Source: Karunakaran N (2015), "Growth of crop-output in Kerala: Is it real or monetary", Artha Journal of social science, 14(4): 104

Table 12 shows the decomposition of growth of output of arecanut crop in Kerala from 1960-61 to 2013-14 and revealed that the growth is monetary in nature rather than real growth.

\section{Conclusion}

During the past five decades and more, arecanut cultivation in Kerala underwent expansion in area under cultivation associated with increase in production. The analysis of inter-district performance supports this finding. A comparison of the compound growth rates of arecanut productivity during the five periods revealing slight increase in the growth of arecanut productivity and supporting it. During the period since the middle of 1980 with regard to area and production, the coefficient of variation was higher as compared to 1960's and 1970's. During this period, significant increase in production had occurred consequent to increase in area (area effect) and the productivity of arecanut remains almost stagnant. And, since 1985, change in production was mainly due to yield effect. The analysis of growth of output of arecanut crop in Kerala has revealed that the growth is mainly monetary in nature rather than real growth. 
N Karunakaran Area, Production and Productivity of Arecanut in Kerala

\section{References}

Duggappa , MC. (2013). "Problems and Prospects of Arecanut Growers of Non-Malnad areas in Western Karnataka", Southern Economist, 52(2): 23-26.

George, V. T., Krishnakumar, V., Maheswarappa, H.P., Bhat, R. and Balasimha, D. (2011).Arecanut based cropping and farming systems, Indian Council of Agricultural Research,Central Plantation Crops Research Institute, Kasaragod, India.

Govt. of India. (2014).Cocoa, Arecanut and spices statistics, Ministry of agriculture, Directorate of Cocoa, Arecanut and Spices Development, Kozhikkode,India.

Govt. of India. (2015).Agricultural Statistics at a Glance-2014, Ministry of agriculture, Directorate of Economics and Statistics, New Delhi,India.

Jose, C.T., and Jayasekhar. (2008). "Growth trends in area, production and productivity of arecanut in India", Agricultural Situation in India, 65(3): 135-140.

Karunakaran, N. (2013). “Arecanut marketing in Kerala: method of sale and channels", Agricultural Situation in India, 70(4): 15-20.

Karunakaran, N. (2014). "Impact of a cooperative society on the Arecanut marketing in Kerala: a case study of CAMPCO Ltd", Agricultural Economics Research Review, 27 (conference issue): 135-140.

Karunakaran, N. (2015). "Arecanut cultivation in Kerala: Trend, cost of production and marketing", Prakathi, 131-132: 64-73.

Karunakaran, N. (2015).Crop Diversification for Sustainable Agriculture, Pointer publishers, Jaipur, India: 83-105.

Karunakaran, N. (2015)."Growth of crop-output in Kerala: Is it real or monetary",Artha Journal of social science, 14(4): 89-109.

Sathyendra Kumar A.D., Chandrashekar, H.M. (2015). "Production performance of selected Horticultural commodities in Karnataka", International Journal of Management Research and Review, 5(9): 669-675. 